\title{
KONDISI KEUANGAN, OPINION SHOPPING DAN OPINI AUDIT GOING CONCERN PADA PERUSAHAAN PERTAMBANGAN YANG TERDAFTAR DI BEI
}

\author{
Bahtiar Effendi \\ Fakultas Ekonomi, Bisnis dan Ilmu Sosial, Universitas Matana \\ E-mail: bahtiar.effendi@matanauniversity.ac.id
}

\begin{abstract}
Going concern audit opinion is the auditor's opinion to ascertain whether the company can maintain the survival of the entity. The importance of disclosing the company's survival will have an impact on steakholder valuation and trust. The purpose of this study was to determine the effect of financial conditions, opinion shopping and disclosure on going concern audit opinions on mining companies listed on the Indonesia Stock Exchange (IDX) during the period between 2014-2017.

The population in this study are mining companies listed on the Indonesia Stock Exchange in the 2014-2017 period. The company becomes a sample based on the purposive sampling method chosen by certain criteria. The type of data used in this study is secondary data. Data analysis using multiple linear regression methods using SPSS 24 as an analysis tool.

The results of the study show that Opinion shopping has a negative effect on the going concern audit opinion while disclosure has a positive effect on the going concern audit opinion.
\end{abstract}

Keywords: Financial conditions, Opinion Shopping, Disclosure and Going Concern Audit Opinion.

\section{Pendahuluan}

Menurut SPAP tahun 2017, kondisi keuangan dapat mengambarkan kemampuan suatu entitas di masa yang akan datang. Kondisi keuangan yang buruk akan memberi dampak pada kelangsungan hidup entitas, yang menjadi pertanyaan apakah mampu dalam menghadapi kondisi di masa yang akan datang? Jika suatu entitas memiliki kondisi keuangan yang dinilai tidak mampu maka akan memberi dampak kepada pemangku kepentingan. Informasi yang diterima dari kondisi keuangan yang buruk tidak akan diterima oleh para steakholder.

Salim dan Rahayu (2014) menjelaskan fenomena tentang opini audit going concern mulai muncul di Indonesia ketika beberapa kasus dilikuidasinya lembaga perbankan yang pada tahun sebelumnya menerima unqualified opinion (opini wajar tanpa pengecualian), yaitu Bank Global International, Uni Bank, Bank Prasidha Utama, Bank Summa, Bank Asiatic, Bank Ratu, dan Bank Dagang Bali. Faktanya Penulis melihat bahwa kesadaran tetang pentingnya opini audit going concern masih rendah terutama pada perusahan pertambangan. Pentingnya opini going concern untuk keberlangsungan hidup suatu entitas bagaimana entitas harus tetap eksis di masa yang akan datang. Penulis menemukan sebanyak 41 perusahaan pertambangan yang terdaftar di BEI tahun 2017 hanya 35\% perusahaan atas opini going concern. Penulis telah mengolah data dan infomasi tentang kesadaran perusahaan 
pertambangan mempublikasikan laporan keuangan (financial report) dan laporan tahunan (annual report) dari tahun 2014 - 2017. Data tersebut membuktikan bahwa kecenderungan naik turunnya kesadaran untuk mempublikasikan laporan keuangan dan laporan tahunan. Hal itu membuktikan bahwa rendahnya tingkat kesadaran perusahaan di Indonesia untuk keberlangsungan usaha dimasa depan.

Penelitian tentang going concern masih menjadi masalah mendasar didalam dunia bisnis, dibutuhkan faktor penentu sebagai acuan yang pasti untuk menentukan status going concern pada perusahaan dan kekonsistenan faktor- faktor tersebut harus diuji agar dalam keadaan ekonomi yang fluktuatif status going concern tetap dapat diprediksi (Siti, 2010). Faktor-faktor yang mempengaruhi opini audit going concern ada dua faktor yaitu faktor internal dan eksternal. Menurut Novialina (2012) menjelaskan faktor internal yang dapat mengancam kelangsungan hidup perusahaan, misalnya manipulasi dan kejahatan akuntansi yang dilakukan oleh pihak manajemen perusahaan. Sedangkan faktor eksternal misalnya meningkatnya harga energi, pemberian insentif yang tidak terarah, ketidakpastian hukum, kebijakan perburuhan yang membuat produktivitas rendah serta makin ketatnya persaingan di pasar global membuat sektor industri nasional semakin terpuruk.

Opini audit going concern adalah opini auditor untuk memastikan apakah perusahaan dapat mempertahankan kelangsungan hidup entitas. Kajian atas opini audit going concern dapat dilakukan dengan melihat kondisi internal perusahaan, seperti kualitas audit, kondisi keuangan perusahaan, opini audit tahun sebelumnya, pertumbuhan perusahaan dan opinion shopping. Kondisi keuangan menjadikan pengeluaran opini audit going concern sangat berguna bagi para pemakai laporan keuangan untuk membuat keputusan yang tepat dalam berinvestasi, karena ketika seorang invertor akan melakukan investasi maka perlu untuk mengetahui kondisi keuangan perusahaan, terutama yang menyangkut tentang kelangsungan hidup perusahaan tersebut (Hani et.al., 2003).

Praptitorini (2011) melalui Securities and Exchange Commission menjelaskan opinian shopping merupakan suatu aktivitas mencari auditor yang dapat mendorong dan membantu perlakuan akuntansi yang diajukan oleh manajemen untuk mencapai tujuan pelaporan perusahaan. Tujuannya adalah memanipulasi hasil operasi atau kondisi keuangan. Teoh (1992) menjelaskan bahwa dalam kondisi tersebut perusahaan biasanya melakukan pergantian auditor untuk menghindari opini going concern. Karena tekanan semacam itu auditor yang tidak mau diganti harus mengeluarkan opini yang diharapkan oleh perusahaan. Febrian (2015) menyatakan apabila perusahan harus menerima audit going concern mengakibatkan manajemen melakukan pergantian auditor yang disebut fenomena opinion shopping.

Penelitian sebelumnya dilakukan oleh Iriawan dan Suzan (2015) menyatakan jika perusahaan-perusahaan berhasil melakukan opinion shopping maka kemungkinan perusahaan mendapatkan opini audit going concern akan semakin kecil, begitu juga sebaliknya. Sehingga membuktikan bahwa opinion shopping berpengaruh negatif terhadap opini audit going concern. Membantah penelitian Iriawan dan Suzan (2015), penelitian yang dilakukan oleh Ni Putu Evi Kusumayanti dan Ni Luh Sari Widhiyani (2017) dengan judul pengaruh opinion shopping, disclosure dan reputasi KAP pada opini audit going concern. Penelitian tersebut dalam penentuan samplenya mengunakan metode non probability sampling dengan teknik purposive sampling. Hasil penelitian tersebut memberikan bukti opinion shopping dan disclosure berpengaruh positif terhadap opini audit going concern. Penelitian lainnya terkait opini audit going concern dengan mengunkan variable lain dilihat dari sisi kondisi keuangan dan non keuangan pada entitas yang dilakukan Kartika (2012). Menurut penelitian tersebut penentuan sample mengunakan teknik purposive sampling. Hasil penelitian ini menunjukkan kondisi keuangan, kualitas audit, dan opinion shopping tidak berpengaruh terhadap penerimaan opini going concern sedangkan opini audit tahun sebelumnya dan pertumbuhan 
perusahaan berpengaruh terhadap penerimaan opini going concern. Penlitian selanjutnya adalah Effendi (2019) dengan judul kualitas audit, kondisi keuangan, ukuran perusahaan dan penerimaan opini audit going concern menyatakan bahwa baik kualitas audit maupun kondisi keuangan tidak berpengaruh terhadap opini audit going concern.

\section{Tinjauan Literatur dan Pengembangan Hipotesis}

Agency Theory. Jensen dan Meckling (1976) menjelakan keterkaitan menejer (agent) dan pemilik (principal) dalam satu atau lebih kontrak untuk menjalankan dan melaksanakan wewenang serta tanggung jawab pengambilan keputusan kepada agent. Karena adanya moral hazard, manajer tidak melakukan tugas dan wewenangnya sesuai dengan keinginan shareholders atau principal. Perbedaan kepentingan tersebut perlunya pengawasan dan penelitian kembali laporan menejer kepada principal. Adanya pihak ketiga yang independen dibutuhkan sebagai penengah (mediator) antara agent dan principal. Menurut Setiawan (2006), auditor adalah pihak yang dianggap mampu sebagai pihak ketiga yang independen sebagai jembatan kepentingan agent dan principal. Auditor akan memastikan dan memonitor bahwa pelaksanakan wewenang oleh menejer sesuai dengan peraturan serta telah bertindak sesuai dengan keinginan principal dalam bentuk opini audit. Opini audit yang dikeluarkan mengenai kewajaran pelaporan serta memberikan saran dengan mempertimbangan kelangsungan hidup suatu entitas (going concern).

Going Concern. Going concern adalah keberlanjutan atau keberlangsungan hidup. Suatu entitas atau badan usaha harus mempertimbangkan kelanjutan usaha di masa yang akan datang. Setiawan (2006) menjelaskan bahwa going concern menjadikan dasar asumsi suatu entitas dapat bertahan dan berkelanjutan hidup usahanya secara langsung mempengaruhi laporan keuangan. Adanya going concern suatu entitas dinilai mampu mempertahankan eksistensi usahanya dalam jangka panjang dan tidak akan likuidasi jangka pendek (Andika, 2012). Berdasarkan IAI (2017) laporan keuangan biasanya disusun atas dasar asumsi kelangsungan usaha entitas dimana perusahaan akan melanjutkan usahanya di masa depan tidak bermaksud atau berkeinginan melikuidasi atau mengurangi secara material skala usahanya. Jika terjadi sebaliknya, maka laporan keuangan harus disusun dengan dasar yang berbeda dan dasar yang digunakan harus diungkapkan.

Opini Audit Going Concern. Berdasarkan SPAP 2017, Opini audit memodifikasi terkait going concern yang merupakan opini audit dalam pertimbangan auditor dimana terdapat ketidakmampuan atau ketidakpastian signifikan atas kelangsungan hidup perusahaan dalam menjalankan operasinya pada kurun waktu yang pantas, tidak lebih dari satu tahun sejak tanggal laporan keuangan yang sedang diaudit. Auditor dalam melakukan pemeriksaan harus dapat menganalisis dari laporan keuangan dan aktifitas opersioanal suatu entitas pada laporan audit dengan pertimbangan going concern. Andika (2012) menjelaskan pertimbangan auditor yang mendasar dalam aspek going concern terlihat dalam menganalisis hasil dari operasi, kondisi ekonomi yang mempengaruhi perusahaan, kemampuan membayar hutang dan kebutuhan likuidasi di masa yang akan datang.

Kondisi Keuangan. Kondisi keuangan mengambarkan kondisi atau keadaan perusahaan dilihat dari laporan keuangannya. Menurut Andika (2012) kondisi keuangan mengambarkan kondisi kesehatan perusahaan, indikasi apakah perusahaan dalam kondisi sehat atau buruk dilihat dari rasio keuangan perusahaan. Menurut Petronela (2004) perusahaan yang sehat tingkat profitabilitasnya tinggi dan laporan keuangan wajar dan memungkinkan akan mendapatkan opini yang baik dibandingkan jika tingkat profitabilitasnya rendah. Andika 
(2014) menjelaskan perusahaan yang mempunyai kas yang cukup untuk memenuhi kewajiban keuangan perusahaan, besarnya piutang yang logis, efisiensi manajemen persediaan, perencanaan investasi yang baik dan struktur modal yang sehat sehingga memaksimalkan pencapaian tujuan perusahaan.

Opinion Shopping. Opinion shopping terjadi apabila perusahaan akan memberhentikan auditor yang cenderung memberikan opini audit berupa opini audit going concern, atau sebaliknya bahwa perusahaan akan menunjuk auditor yang cenderung memberikan opini audit berupa unqualified opinion. Perusahaan melakukan praktik opinion shopping bukan tanpa alasan, perusahaan melakukan ini dengan harapan mendapat unqualified opinion dari auditor baru. Hal tersebut dibuktikan dengan pernyataan Lennox (2000) bahwa perusahaan yang mengganti auditor (auditor switching) kemungkinan akan memperoleh opini yang lebih baik jika dibandingkan dengan perusahaan yang tidak mengganti auditornya.

Keterkaitan Kondisi Keuangan Terhadap Opini Audit Going Concern. Keraguan yang besar terhadap kemampuan perusahaan untuk melanjutkan usahanya dapat ditunjukkan dengan terjadinya kegagalan keuangan (financial distress) atau kondisi keuangan yang memburuk. Tingkat kesehatan suatu perusahaan dapat dilihat dari kondisi keuangan perusahaan. Perusahaan yang mempunyai kondisi keuangan yang baik maka auditor tidak akan mengeluarkan opini audit going concern (Ramadhany, 2004). Menurut penelitian Kartika (2012) Auditor biasanya akan mempertimbangkan kondisi keuangan ketika memberikan opini audit going concern. Kondisi keuangan yang buruk akan mendorong auditor untuk cenderung memberikan opini audit going concern. Kondisi keuangan ini digambarkan dari rasio keuangan profitabilitas dan likuiditas. Profitabilitas perusahaan menunjukkan kemampuan perusahaan dalam menghasilkan keuntungan. Semakin kecil profitabilitas menunjukkan bahwa perusahaan mengalami penurunan kemampuan dalam kegiatan operasinya. Hal ini akan mendorong auditor untuk cenderung memberikan opini audit going concern. Hasil penelitian Kartika (2012) menunjukanan bahwa kondisi keuangan yang diproksikan oleh profitabilitas dan likuiditas berpengaruh negatif pada penerimaan opini audit going concern. Berbeda dengan hasil penelitian yang dilakukan Effendi (2019) yang menemukan bahwa kondisi keuangan tidak berpengaruh terhadap opini audit going concern. Effendi (2019) menyatakan bahwa kondisi ini terjadi ketika auditor mempertimbangkan faktor lain seperti kondisi ekonomi, atau pertumbuhan perusahaan.

$\mathrm{H}_{1}$ : Kondisi keuangan berpengaruh terhadap opini audit going concern.

Keterkaitan Opinion Shopping Terhadap Opini Audit Going Concern. Opinion shopping didefinisikan oleh SEC, sebagai aktivitas mencari auditor yang mau mendukung perlakuan akuntansi yang diajukan oleh manajemen untuk mencapai tujuan pelaporan perusahaan. Menurut penelitian Ni Putu et al. (2017) membuktikan bahwa walaupun auditor mendapatkan tekanan dari pihak manajemen, auditor akan tetap menjaga independensinya untuk menghasilkan audit yang berkualitas. Ketika manajemen mengancam auditor untuk melakukan auditor switching, auditor tidak akan terpengaruh dan tetap mengeluarkan opini audit going concern. Bukti empiris menunjukan auditor telah bersikap independen dalam mengaudit serta memberikan opininya meskipun terdapat praktik opinion shopping namun hal tersebut tidak menggagalkan auditor untuk memberikan opini audit going concern kepada entitas tersebut. Hasil dari penelitian Ni Putu et al. (2017) menujukan bahwa opinion shopping berpengaruh positif pada opini audit going concern. Pemberian opini audit oleh auditor terhadap perusahaan akan berpengaruh terhadap kelangsungan hidup dan berdampak pada pengambilan keputusan, strategi dan rencana perusahaan kedepan. Apabila opini audit yang diterima perusahaan tidak sesuai dengan yang diharapkan, maka perusahaan. akan 
berusaha untuk mendapat opini yang diinginkan. Salah satu cara yang dapat dilakukan perusahaan untuk mendapat opini tersebut yaitu dengan cara melakukan pergantian auditor (auditor switching). Diharapkan dengan melakukan pergantian auditor (auditor switching), auditor yang baru bisa memberikan opini yang diinginkan oleh perusahaan. Sehingga pada penelitian Suharjono (2014) menunjukan bahwa opinion shopping berpengaruh negatif pada opini audit going concern.

$\mathrm{H}_{2}$ : Opinion shopping berpengaruh terhadap opini audit going concern.

\section{Metode Penelitian}

Populasi penelitian yakni seluruh perusahaan pertambangan yang listing di Bursa Efek Indonesia tahun 2014 hingga 2017, yaitu sejumlah 41 perusahaan. Metode pemilihan sampel dalam penelitian ini yaitu menggunakan metode non probability sampling dengan teknik purposive sampling. Data yang diperoleh dari penentuan sampel yakni sebanyak 22 perusahaan dengan periode pengamatan 2014-2017. Kriteria pertama yaitu perusahaan yang tidak delisting dan terdaftar berturut-turut selama periode pengamatan yaitu 2014-2017. Kriteria kedua yaitu perusahaan pertambangan yang menerbitkan data annual report dan financial report yang telah diaudit oleh auditor independen selama periode 2014-2017. Kriteria ketiga yaitu perusahaan yang pernah mengalami kerugian sekurangnya satu periode laporan keuangan selama periode pengamatan tahun 2014-2017.

Pengumpulan data dilakukan dengan menggunakan metode observasi nonparticipant yaitu dengan melihat data melalui catatan pada laporan keuangan di BEI. Pengolahan data penelitian menggunakan teknik analisis regresi yakni dengan menggunakan program SPSS versi 24.

Variabel Dependen. Variable dependen dalam penelitian ini mengunakan opini audit going concern. Pengukuran opini audit going concern adalah menggunakan variabel dummy, dimana kategori 1 diberikan kepada perusahaan yang terhindar atau tidak menerima opini audit going concern sedangkan kategori 0 diberikan kepada perusahaan yang masih menerima opini audit going concern. Opini audit going concern terdapat pada unqualified opinion with modified wording or explanatory paragraph, qualified opinion, adverse opinion, dan disclaimer of opinion atau no opinion. Sedangkan non opini audit going concern terdapat pada unqualified opinion.

Variabel Independen. Terdapat dua variabel independen dalam penelitian, yaitu kondisi keuangan dan opinion shopping sebagai faktor yang mempengaruhi opini audit going concern.

Kondisi Keuangan. Pengukuran variabel independen kondisi keuangan mengunakan rasiorasio keuangan. Salah satu model prediksi kebangkrutan untuk mengukur kondisi perusahaan yaitu model revised Edward I Altman yang terkenal dengan nama $Z$ Score. Model Revised Altman Z Score diformulakan sebagi berikut:

$$
Z^{\prime}=0.717 Z 1+0.847 Z 2+3.107 Z 3+0.420 Z 4+0.998 Z 5
$$

Keterangan:

$\mathrm{Z} 1=$ Working capital/total asset

$\mathrm{Z} 2=$ Retained earning/total asset

$\mathrm{Z} 3=$ Earning before interest and taxes/total asset

$\mathrm{Z4}=$ Book value of equity/book value of debt

$\mathrm{Z} 5=$ Sales/total asset 
Klasifikasi perusahaan yang sehat dan bangkrut didasarkan pada nilai Zscore model Altman revisi yaitu :

1. Jika nilai $\mathrm{Z}<1,81$ maka termasuk perusahaan tersebut dapat dikategorikan sebagai perusahaan yang berisiko tinggi terhadap kebangkrutan;

2. Jika nilai $1,81<\mathrm{Z}<2,99$ maka termasuk grey area (tidak dapat ditentukan apakah perusahaan sehat ataupun mengalami kebangkrutan);

3. Jika nilai $Z>2,99$ maka termasuk perusahaan yang tidak bangkrut, perusahaan tersebut dapat dikategorikan sebagai perusahaan sehat atau perusahaan bebas dari masalah kebangkrutan (non bankrupt company).

Opinion Shopping. Pengukuran variable independen opinion shopping dengan variabel dummy sudah diterapkan Lenox (2002). Metode yang diterapkan oleh Lennox (2002) dengan ketentuan sebagai berikut: kode 1 diberikan kepada perusahaan yang melakukan pergantian auditor dan kode 0 diberikan jika perusahaan tidak melakukan pergantian auditor.

\section{Hasil Penelitian dan Pembahasan}

Statistik Deskriptif. Statistik deskriptif menjelaskan mengenai karakteristik data seperti nilai minimum, nilai maksimum, rata-rata, dan standar deviasi dari data yang digunakan.

Tabel 1. Statistik Deskriptif

\begin{tabular}{|l|r|r|r|r|r|}
\hline \multicolumn{7}{|c|}{ Statistik Deskripsi } \\
\hline & N & Minimum & Maximum & Mean & $\begin{array}{c}\text { Std. } \\
\text { Deviatio } \\
\mathbf{n}\end{array}$ \\
\hline Kondisi Keuangan & 37 & .22 & 4.94 & 2.123 & 1.20602 \\
\hline Opinion Shopping & 37 & .00 & 1.00 & .0541 & .22924 \\
\hline $\begin{array}{l}\text { Opini Audit } \\
\text { Going Concern }\end{array}$ & 37 & .07 & .18 & .1143 & .03376 \\
\hline Valid N (listwise) & 37 & & & & \\
\hline
\end{tabular}

Sumber: Pengujian dengan SPSS 24.00

Berdasarkan Tabel 1 di atas menunjukan jumlah sample penelitian (N) adalah 37 perusahaan pada laporan keuangan dan laporan tahunan yang merupakan perusahan pertambangan yang terdaftar di BEI tahun 2014-2017. Variabel kondisi keuangan yang diproksikan dengan $Z$ Score menunjukkan bahwa nilai $Z$ Score minimum yang dihasilkan adalah sebesar 0,22 dan nilai $Z$ Score maksimum adalah 4,94. Rata-rata nilai $Z$ Score perusahaan yang menerima opini audit going concern adalah sebesar 2.1235. Perusahaan yang kondisi keuangannya baik adalah PT. Samindo Resources Tbk. pada tahun 2016, sedangkan perusahaan yang rendah kondisi keuangannya dan yang rentan akan kebangkrutan adalah PT. Aneka Tambang Tbk. pada tahun 2017.

Variabel selanjutnya adalah opinion shopping yang diukur dengan variable dummy pada uji statistik diskriptif menunjukan bahwa nilai minimum yang dihasilkan adalah 0 dan nilai maksimum adalah 1 . Nilai rata-rata perusahan melakukan opinion shopping adalah 0.0541. Menurut Ghozali (2006) variable yang diukur dengan variable dummy memiliki skala nominal sehingga tidaklah tepat menghitung nilai rata-rata dan standar deviasi dari variabel tersebut. Adapun perusahaan yang paling tinggi melakukan praktik opinion shopping adalah 
PT. Bukit Asam Tbk. pada tahun 2016 dan PT. Elnusa Tbk. pada tahun 2015. Variabel dependen yaitu going concern diukur dengan menggunakan dummy variabel (mempunyai skala nominal). Pengukuran ini sama dengan opinion shopping yang tidak tepat menghitung nilai rata-rata dan standar deviasi dari variabel tersebut. Perusahaan yang mendapatkan nilai terendah untuk perusahaan yang mendapatkan opini audit going concern adalah PT. Citatah Tbk. pada tahun 2014, PT. Resource Alam Indonesia Tbk. pada tahun 2015, PT. Mitrabara Adiperdana Tbk. pada tahun 2015. Sedangkan untuk perusahaan yang mendapatkan nilai tertinggi terkait opini audit going concern adalah PT. Elnusa Tbk. pada tahun 2017.

Uji Asumsi Klasik. Dalam suatu pengujian analisis regresi berganda, wajib dilakukan pengujian asumsi klasik karena dapat diketahui apakah data yang kita gunakan untuk penelitian layak dipakai atau tidak. Pengujian asumsi klasik yang dilakukan adalah uji normalitas, uji multikolinearitas, uji heteroskedastisitas, dan uji autokorelasi. Data yang digunakan harus bebas dari penyimpangan asumsi klasik.

Uji Normalitas. Uji normalitas berfungsi sebagai penguji untuk mengetahui kenormalan distribusi variabel dependen dan independen. Uji normalitas pada penelitian ini menggunakan pada chart histogram, grafik P-P plot sebagai berikut:

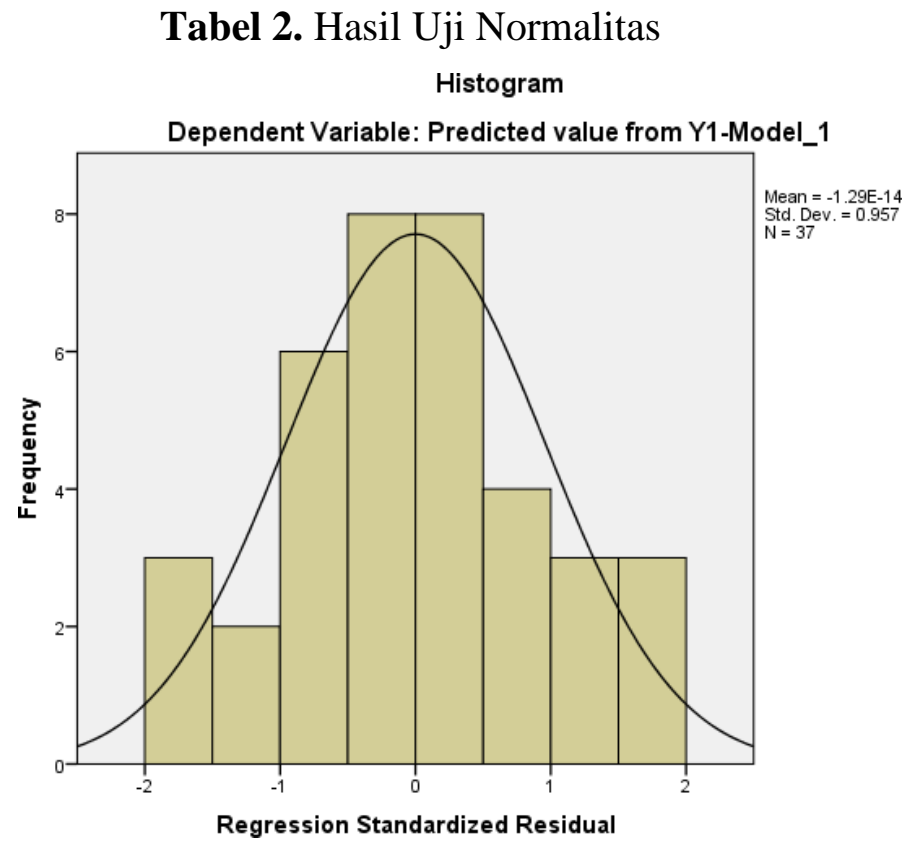

Sumber: Pengujian dengan SPSS 24.00

Hasil penelitian dengan mengunakan uji normalitas dengan chart histogram sebagaimana di sajikan dalam Tabel 2 menunjukan bahwa distribusi variabel dependen dan variabel independen berdistribusi normal karena chart mengambarkan data yang normal mengikuti garis bentuk normal.

Selanjutnya, hasil pengujian normalitas berikutnya ditunjukkan dalam Tabel 3 di bawah ini. Berdasarkan Tabel 3 tersebut menunjukan bahwa data yang digunakan dalam penelitian ini dapat diasumsikan memiliki distribusi normal karena sebaran data cenderung dekat dengan garis melintang dan titik-titik mengikuti garis diagonal. Jadi dapat disimpulkan bahwa chart histogram dan grafik P-P plot yang disajikan dalam Tabel 2 dan Tabel 3 menjelaskan bahwa model regresi memenuhi asumsi normalitas. 
Tabel 3. Hasil Uji Normalitas

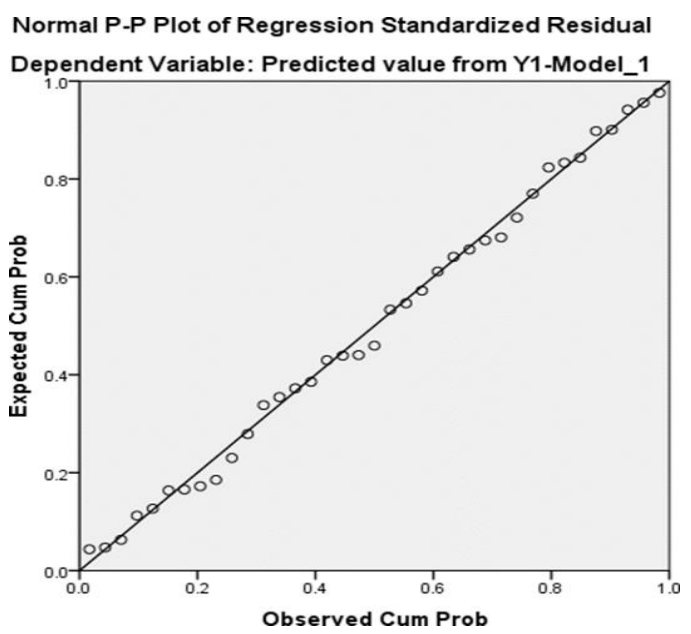

Sumber: Pengujian dengan SPSS 24.00

Uji Multikolinearitas. Uji Multikolinearitas berfungsi untuk mengetahui ada atau tidaknya penyimpangan asumsi klasik multikolinearitas dengan dibuktikannya adanya hubungan linear antar variabel independen dalam model regresi. Syarat yang harus terpenuhi dalam model regresi pengujian ini adalah tidak adanya multikolinearitas. Hasil uji multikolinearitas dengan menggunakan inflation factor (VIF), sebagai berikut:

Tabel 4. Hasil Uji Multikolinearitas

\begin{tabular}{|c|c|c|c|}
\hline \multicolumn{4}{|c|}{ Coefficient $^{a}$} \\
\hline \multirow{2}{*}{\multicolumn{2}{|c|}{ Model }} & \multicolumn{2}{|c|}{ Collinearity Statistics } \\
\hline & & Tolerance & VIF \\
\hline 1 & (Constant) & & \\
\hline & Kondisi Keuangan & .964 & 1.037 \\
\hline & Opinion Shopping & .975 & 1.026 \\
\hline
\end{tabular}

Sumber: Pengujian dengan SPSS 24.00

Berdasarkan Tabel 4 di atas, dapat disajikan bahwa data yang digunakan dalam penelitian ini dapat diasumsikan terbebas dari multikolinearitas karena nilai yang tercantum dalam VIF tidak melebihi 10 dan nilai Tolerance di atas 0,1 .

Uji Heteroskedastisitas. Uji heteroskedastisitas bertujuan untuk menguji dalam model regresi terjadi kesamaan atau ketidaksamaatuan varian dari residual satu pengamatan kepengamatan yang lain. Model regresi yang baik adalah tidak terjadi heteroskedastisitas atau homokedastisitas. Dalam penelitian ini, uji heteroskedastisitas data dilakukan dengan melihat penyebaran dari varians residual dalam grafik scatterplot. Jika plot menyebar secara terpencar dan tidak membentuk pola tertentu maka dapat disimpulkan bahwa tidak terjadi masalah heteroskedastisitas. Hasil uji heteroskedastisitas dengan menggunakan grafik scatterplot disajikan dalam Tabel 5 berikut ini: 


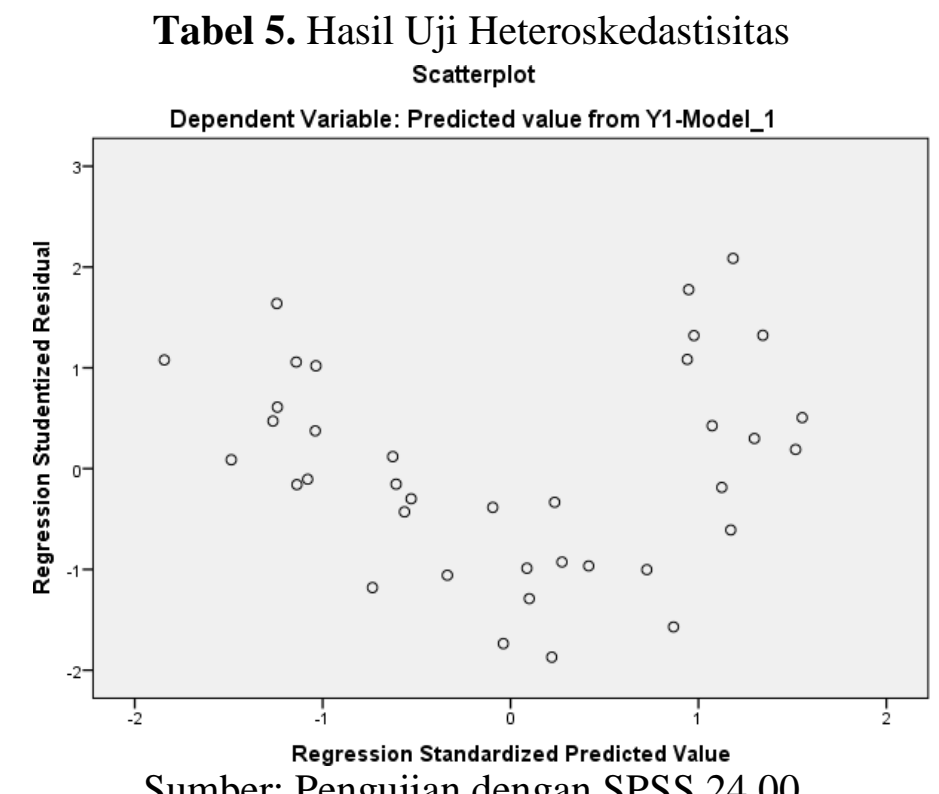

Berdasarkan Tabel 5 di atas menunjukan bahwa data yang digunakan dalam penelitian ini dapat diasumsikan terbebas dari heteroskedastisitas karena sebaran data yang terdapat dalam scatterplot yang tersebar secara merata dan disamping itu cenderung tidak membentuk suatu pola.

Uji Autokorelasi. Uji autokorelasi berfungsi untuk menguji dalam model regresi linier ada atau tidak ada kolerasi antar kesalahan pengganggu pada periode $\mathrm{t}$ dengan kesalahan pengganggu pada periode $\mathrm{t}-1$ atau periode sebelumnya. Hasil uji autokorelasi dengan menggunakan Durbin- Watson disajikan dalam Tabel 6 sebagai berikut:

Tabel 6. Hasil Uji Autokorelasi

\begin{tabular}{|c|c|c|c|c|c|}
\hline \multicolumn{6}{|c|}{ Model Summary $^{\mathbf{b}}$} \\
\hline Model & R & R Square & $\begin{array}{c}\text { Adjuted R } \\
\text { Square }\end{array}$ & $\begin{array}{c}\text { Std. Error } \\
\text { of the } \\
\text { Estimate }\end{array}$ & $\begin{array}{c}\text { Durbin- } \\
\text { Watson }\end{array}$ \\
\hline 1 & $.906^{\mathrm{a}}$ & .821 & .804 & .01494 & 1.028 \\
\hline
\end{tabular}

Sumber: Pengujian dengan SPSS 24.00

Berdasarkan Tabel 6 tentang hasil pengujian autokorelasi menunjukan bahwa data yang digunakan dalam penelitian ini terbebas dari adanya autokorealsi dikarenakan nilai Durbin- Watson yang terdapat dalam tabel model summary tidak lebih besar dari nilai yang Durbin-Watson yang seharusnya. Nilai yang dihasilkan adalah 1,028 yaitu diantara -2 dan 2 atau dapat dituliskan $-2 \leq 1,028 \leq 2$, sehingga dapat disimpulkan bahwa dalam model regresi ini tidak mempunyai autokorelasi.

Pengujian Hipotesis. Penelitian ini menggunakan model regresi berganda untuk menguji hipotesis. Analisis regresi berganda dilakukan untuk mengetahui pengaruh variabel independen terhadap variabel dependen. Tingkat kepercayaan yang digunakan sebesar $95 \%$. 
Tabel 7. Hasil Analisis Regresi Berganda

\begin{tabular}{|c|c|c|c|c|c|c|}
\hline \multicolumn{7}{|c|}{ Coefficients $^{a}$} \\
\hline & & \multicolumn{2}{|c|}{$\begin{array}{c}\text { Unstandardized } \\
\text { Coefficients } \\
\end{array}$} & \multirow{2}{*}{$\begin{array}{c}\text { Standardized } \\
\text { Coefficients } \\
\text { Beta } \\
\end{array}$} & \multirow[b]{2}{*}{$t$} & \multirow[b]{2}{*}{ Sig. } \\
\hline \multicolumn{2}{|c|}{ Model } & B & Std. Error & & & \\
\hline \multirow[t]{3}{*}{1} & (Constant) & -1.603 & .146 & & -10.965 & .000 \\
\hline & Kondisi keuangan & -.002 & .002 & .082 & -1.088 & .285 \\
\hline & Opinion Shopping & -.026 & .011 & -.173 & -2.320 & .027 \\
\hline
\end{tabular}

Sumber: Pengujian dengan SPSS 24.00

Uji t. Uji hipotesis t berfungsi untuk melihat pengaruh secara individu variabel bebas terhadap varibael terikat. Cara menukur uji t dengan mengunakan signifikasi parameter individual, pengujian dilakukan dengan menggunakan tingkat signifikan sebesar 0,05 $(\alpha=5 \%)$. Variable independen dinyatakan berpengaruh terhadap variable dependen jika nilai uji t secara signifikan (sig.) kurang dari 0,05 atau < 0,05 dan sebaliknya jika nilai sig lebih besar dari 0,05 dinyatakan tidak berpengaruh. Hasil uji Hipotesis t dengan menggunakan tabel koefisien disajikan dalam Tabel 8, sebagai berikut:

Tabel 8. Hasil Uji t

\begin{tabular}{|c|c|c|c|c|c|c|}
\hline \multicolumn{7}{|c|}{ Coefficients $^{a}$} \\
\hline & & \multicolumn{2}{|c|}{$\begin{array}{c}\text { Unstandardized } \\
\text { Coefficients }\end{array}$} & \multirow{3}{*}{$\begin{array}{c}\text { Standardized } \\
\text { Coefficients }\end{array}$} & \multirow{3}{*}{$\begin{array}{c}\mathbf{t} \\
-10.965 \\
\end{array}$} & \multirow{3}{*}{$\begin{array}{r}\text { Sig. } \\
.000\end{array}$} \\
\hline \multicolumn{2}{|c|}{ Model } & B & Std. Error & & & \\
\hline \multirow[t]{3}{*}{1} & (Constant) & -1.603 & .146 & & & \\
\hline & Kondisi keuangan & -.002 & .002 & .082 & -1.088 & .285 \\
\hline & Opinion Shopping & -.026 & .011 & -.173 & -2.320 & .027 \\
\hline
\end{tabular}

Sumber: Pengujian dengan SPSS 24.00

Dari tabel di atas dapat disimpulkan bahwa variabel yang berpengaruh terhadap opini audit going concern adalah opinion shopping. Hal ini dapat dilihat pada nilai signifikan (sig.) yang menunjukan hasil kurang dari 0.05. Sedangkan kondisi keuangan dengan nilai 0,285 diatas 0,05 atau $>0,05$.

Berdasarkan hasil Tabel 8 di atas, menunjukan bahwa kondisi keuangan yang diproksikan dengan Atman Z Score menunjukan nilai t hitung sebesar 11,088 dan sig. 0,285. Nilai t hitung bertanda negatif dan nilai signifikasi > 0,05, maka variabel kondisi keuangan tidak berpengaruh negatif terhadap opini audit going concern. Standardized coefficient kondisi keuangan sebesar 0,285 sehingga hipotesis pertama yang mengatakan bahwa kondisi keuangan berpengaruh terhadap opini audit going concern. Kesimpulan uji hipotesis pertama bahwa :

$\mathrm{H}_{1}$ : Kondisi keuangan berpengaruh terhadap opini audit going concern (dinyatakan ditolak). 
Hasil penelitian ini membuktikan bahwa kondisi keuangan yang mengalami kebangkrutan tidak memiliki pengaruh terhadap pemberian opini audit going concern. Bukti empiris menunjukan auditor tidak terpengaruh akan kondisi keuangan sehingga dalam pemberian opini audit going concern dalam kondisi kebangkrutan sekalipun tidak mengagalkan auditor bersikap independen dan memberikan opini audit going concern.

Berdasarkan hasil Tabel 8 juga menunjukan bahwa opinion shopping menunjukan nilai $t$ hitung sebesar $-2,320$ dan sig. 0,027. Nilai t hitung bertanda negatif dan nilai signifikasi $<0,05$, maka variabel opinion shopping tidak berpengaruh negatif terhadap opini audit going concern. Standardized coefficient kondisi keuangan sebesar 0,027 sehingga hipotesis pertama yang mengatakan bahwa kondisi keuangan berpengaruh terhadap opini audit going concern. Kesimpulan uji hipotesis pertama bahwa :

$\mathrm{H}_{2}$ : Opinion shopping berpengaruh terhadap opini audit going concern (dinyatakan diterima).

Hasil penelitian ini membuktikan bahwa auditor mendapatkan tekanan dari pihak manajemen, auditor akan berpengaruh terhadap independensinya untuk menghasilkan audit yang berkualitas. Ketika manajemen mengancam auditor untuk melakukan auditor switching, auditor akan terpengaruh untuk mengeluarkan opini audit going concern. Bukti empiris menunjukan auditor tidak bersikap independen dalam mengaudit serta memberikan opininya terdapat praktik opinion shopping, namun hal tersebut dapat menggagalkan auditor untuk memberikan opini audit going concern kepada entitas tersebut.

Uji F. Uji hipotesis f berfungsi untuk menunjukkan apakah semua variabel independen atau bebas dalam model penelitian mempunyai pengaruh terhadap variabel dependen. Hasil dari uji $\mathrm{F}$ dapat dilihat dari tabel ANOVA dengan standar pengaruh signifikan jika nilai signifikansi $\mathrm{F}$ lebih kecil dari alpha kasus penelitian. Hasil uji Hipotesis $\mathrm{f}$ dengan menggunakan tabel ANOVA, sebagai berikut:

Tabel 9. Hasil Uji F

\begin{tabular}{|c|c|c|c|c|c|c|}
\hline \multicolumn{7}{|c|}{ ANOVA $^{a}$} \\
\hline \multicolumn{2}{|c|}{ Model } & $\begin{array}{c}\text { Sum of } \\
\text { Squares }\end{array}$ & df & Mean Square & $\mathbf{F}$ & Sig. \\
\hline \multirow[t]{3}{*}{1} & Regression & .034 & 3 & .011 & 50.285 & $.000^{\mathrm{b}}$ \\
\hline & Residual & .007 & 33 & .000 & & \\
\hline & Total & .041 & 36 & & & \\
\hline \multicolumn{7}{|c|}{ a. Dependent Variable: Opini Audit Going Concern } \\
\hline \multicolumn{7}{|c|}{ b. Predictors: (Constant), Kondisi Keuangan } \\
\hline
\end{tabular}

Sumber: Pengujian dengan SPSS 24.00

Pengujian kelayakan regresi berganda dilakukan dengan nilai signifikansi sebesar 0,05, dimana hasil $\mathrm{F}$ hitung tabel diatas sebesar 50,285. Nilai probabilitas signifikan menunjukkan nilai yang lebih kecil daripada tingkat signifikansi yang telah di tentukan yaitu $0,05(0,05<0,50)$.

\section{Simpulan dan Saran}

Simpulan. Penelitian ini bertujuan untuk menguji pengaruh kondisi keuangan dan opinion shopping terhadap opini audit going concern pada perusahaan pertambangan yang listing di BEI tahun 2014-2017. Hasil penelitian menunjukkan bahwa kondisi keuangan tidak 
berpengaruh terhadap opini audit going concern, namun opinion shopping berpengaruh negatif signifikan terhadap opini audit going concern.

Saran. Peneliti selanjutnya diharapkan dapat memperluas variabel dengan menguji faktor keuangan, faktor non keuangan dan faktor pasar lainnya yang dapat diduga mempengaruhi opini going concern. Selain itu, peneliti selanjutnya juga disarankan untuk memperluas sampel penelitian, tahun periode penelitian, dan dapat melihat lebih mendalam terkait opinion shopping.

\section{DAFTAR PUSTAKA}

Altman, E. I. 1968. Financial Ratios: Discriminan Analysis and The Prediction of Corporate Bankruptey. Journal of Finance Edition 123.

Effendi, Bahtiar. 2019. Kualitas Audit, Kondisi Keuangan, Ukuran Perusahaan dan Penerimaan Opini Audit Going Concern. Owner: Jurnal Riset dan Akuntansi Vol.3, No.1, Februari 2019: 9-15.

Effendi, Bahtiar. 2019. Profitabilitas, Solvabilitas dan Audit Delay Pada Perusahaan Consumer Goods yang Terdaftar di BEI. Owner: Jurnal Riset dan Akuntansi Vol.2, No.2, Agustus 2018: 100-108.

Ghozali, Imam. 2011. Aplikasi Analisis Multivariate Dengan Program SPSS. Semarang. ISBN. Badan Penerbit Universitas Diponogoro.

Hani, Clearly, dan Mukhlasin. 2003. Going Concern dan Opini Audit: Suatu Studi Pada Perusahaan Perbankan di BEJ. Simposium Nasional Akuntansi VI. pp. 1221-1233.

Ikatan Akuntansi Indonesia. 2017. Standar Profesional Akuntan Publik. Jakarta: Salemba Empat.

Iriawan dan Suzan. 2015. Pengaruh Pertumbuhan Perusahaan, Opinion Shopping, dan Prior Opinion Terhadap Penerimaan Opini Audit Going Concern (Studi Pada Perusahaan Property and Real Estate yang Listing di BEI Tahun 2009-2013). E-Proceeding of Management, Vol. 2, No. 2, Agustus 2015: 1683-1690.

Istiana, Siti. 2010. Pengaruh Kualitas Audit, Opinion Shopping, Debt Default, Pertumbuhan Perusahaan Terhadap Penerimaan Opini Audit Going Concern. Jurnal Akuntansi dan Investasi Vol. XI No. 1, Januari 2010: 74-87.

Jensen, M. C. and Meckling, W.H. 1976. Theory of The Firm, Managerial Behaviour, Agency Costs \& Ownership Structure. Journal of Financial Economics.Vol 3 October. pp. 305-360.

Kartika, Andi. 2012. Pengaruh Kondisi Keuangan dan Non Keuangan terhadap Penerimaan Opini Going Concern pada Perusahaan Manufaktur di BEI. Dinamika Akuntansi Keuangan dan Perbankan, Vol. 1 No.1, Mei 2012.

Lennox, C. 2000. Do Companies Success-fully Engage in Opinion Shoppping: Eevidencefrom the UK. Journall of Accounting and Economics 29.

Ramadhany, Alexander. 2004. Analisis Faktor - Faktor Yang Mempengaruhi Penerimaan Opini Going Concern Pada Perusahaan Manufaktur Yang Mengalami Financial Distress Di Bursa Efek Jakarta. Tesis S2, Universitas Diponegoro, Semarang. Tidak Dipublikasikan.

Lennox, Clive S. 2002. Going-concern Opinions in Failing Companies: Auditor Independence and Opinion Shopping. SSRN Electronic Journal. h:1-26.

Suharjono, Mohammad A. 2014. Pengaruh Opinion Shopping Terhadap Going Concern Opinion Pada Perusahaan Yang Mengalami Financial Distress.

Ni Putu,et al. 2017. Pengaruh Opinion Shopping, Disclosure dan Reputasi KAP pada Opini Audit Going Concern. 
Petronela,Thio. 2004. Perkembangan Going Concern Perusahaan Dalam Pemberian OpiniAudit. Jurnal Balance.

Praptitorini, Mirna Dyah dan Indira Januarti. 2011. Analisis Pengaruh Kualitas Audit, Debt Default, dan Opinion Shopping Terhadap Penerimaan Opini Going Concern. Jurnal Akuntansi dan Keuangan Indonesia.Volume 8 No 1, Juni 2011.

Salim, A., dan Rahayu, S. 2014. Pengaruh Opini Audit, Ukuran KAP, Pergantian Manajemen, dan Financial Distress Terhadap Auditor Switching. eProceeding of Management. 1. 388.

Setiawan, Santy. 2006. "Opini Going Concern dan Prediksi Kebangkrutan Perusahaan." Jurnal Ilmiah Akuntansi Volume V No. 1, Mei 2006: 59-67.

Teoh, S. 1992. Auditor Independence, Dismissal Threats, and The Markets Reaction to Auditor Switches. Journal of Accounting Research 30. Pp 1- 2. 